\title{
TERF2 wt Allele
}

National Cancer Institute

\section{Source}

National Cancer Institute. TERF2 wt Allele. NCI Thesaurus. Code C52494.

Human TERF2 wild-type allele is located in the vicinity of $16 q 22.1$ and is approximately 30 $\mathrm{kb}$ in length. This allele, which encodes telomeric repeat-binding factor 2 protein, plays a role in the inhibition of aberrant chromosomal polymerization. 